\title{
SIGNS AND SYMBOLS: RELIGIOS AND NATIONAL DIMENSIONS
}

\author{
IVAN OSTASHCHUK
}

\begin{abstract}
The central issues of this paper are the semantic content and the conceptual interpretation of the notions of symbol and sign in philosophical and religious, linguistic and cultural contexts; the relationship between the logic of symbolic thought and communication. The paper highlights the importance of symbols and signs for transmitting information in religious and national universums.
\end{abstract}

Keywords: symbol, sign, religious world view, national code, communication.

Signs and symbols are important elements of the religious and national dimensions of communicative space; their polysemanticity is revealed through human communication, world view, and self-identification.

The aim of this work is to discuss the semantic range of the notions of symbol and sign in the context of religious and national discourse; its tasks are as follows:

- to study the etymology of the word symbol;

- to present the logic of symbolic thought;

- to examine the difference between the notions of symbol and sign;

- to define the role of symbols and signs in religious and national communication.

This study is based on the theories developed by S. Averintsev, R. Barthes, M. Bakhtin, E. Cassirer, A. Losev, Yu. Lotman, M. Mamardashvili, A. Piatigorsky, E. Sapir, K. Jung, and others.

Symbol is a high-frequency polysemantic word. It is one of the basic notions of religious studies, philosophy, aesthetics, art criticism, linguistics, literary criticism, and other fields of the arts.

The notion of symbol appeared in the ancient times. The ancient Greek word $\sigma v \mu \beta \alpha \lambda \lambda \varepsilon \varepsilon v$ has the following meanings: 'unite' ('join in a single unit'), 'merge', 'be intertwined', 'add', 'attach' (verbs); 'sign', 'slogan' (nouns). Originally, it was used to designate half of a broken dice or any other object, which recalled the absent half to which it could be reconnected (Umberto Eco) $(\sigma v \mu \beta \alpha \lambda \lambda \varepsilon v v)$. It was a custom to give such pieces of an object to friends and guests so that later people could identify each other by them. They were means of identification (tessera hospitalitatis) passed down in families from generation to generation. Later, stamps were used for this purpose ( $\sigma \varphi \rho \alpha \gamma \iota \varsigma)$ [21, p. 13-14]; [13].

Plato advocated mimesis of cosmic harmony through music which had specific symbolic value.

The Hellenists did not differentiate between the notions of symbol and allegory.

The Neoplatonians distinguished the sign-nature of Greek handwriting from the symbolic nature of the ancient Egyptian hieroglyphs and pointed out the difference between the mythological symbol and the theological or didactic formula. 
In the Middle Ages, they still regarded symbol and allegory as similar concepts.

In the Renaissance period, the emphasis was on the intuitive perception of a symbol with its flexibility and polysemanticity, which affected the esthetics of Classicism and Baroque.

The Romantics focused on the aesthetic aspect of a symbol. F. Creuzer (Symbolism and Mythology of the Ancients, Especially the Greeks, 1810 -1812) contrasted mystical symbols (explosion of encapsulated form as the expression of the world's infinity) and plastic symbols (attempts to fit the immensity of meaning into encapsulated form). J. W. Goethe related elusiveness, the holistic nature of symbol to its vital organicity revealed through ever-lasting becoming. G. W. F. Hegel focused on rationalistic, conventionally determined sign content in the structure of a symbol [12, vol. 2, p. 389].

Saint Justin (the first half of the $2^{\text {nd }}$ century) was the first Christian philosopher to use symbolon as a synonym to typos. The Fathers of Church regarded the notion of symbol as belonging to the sphere of religion; from this perspective they analyzed the relationship between the Old and the New Testaments, liturgical action, rituals. In the $4^{\text {th }}$ century, the word symbolum became part of the Western Church's vocabulary. For example, Tertullian (p. 155-p. 240 AD) referred to baptism as the symbol of death and resurrection of Christ. Cyprian (p. 200-258 AD) interpreted symbol as the 'symbol of faith' (Credo).

The Middle Ages placed emphasis on subjectivity; in the Carolingian Times, many symbols were borrowed from Roman literature. Sacraments, which Saint Augustine called sacred, were regarded as a special symbol. Still, it should be mentioned that in the Middle Ages, they did not use symbol (and its derivatives symbolic, symbolism) in the modern sense of the word. Symbolum was used mostly by the clergy in reference to the Creed issues. The semantic field of this concept also encompassed signum (sign), figura, imago (image), typus, allegoria, parabola, similitudo (similarity), speculum (mirror) [22].

The philosophical, religious content of a symbol makes it different from a sign, which is regarded as 'a material, sensuously perceived object (event, action, phenomenon), which in the process of cognition functions as indication, designation, representation of another object, event, action, subjective formation' [17, p. 391]. Its main function is 'to acquire, to retain, to transform, and to transmit certain information (message)' [17, p. 391]. The essence of the sign lies only in indication, while the essence of the symbol proves to be more than a mere indication of what the symbol itself is not. Unlike the sign, the symbol is a self-sufficient manifestation of reality. In contrast to signs, symbols cannot be created 'arbitrarily'; they are not products of an individual's imagination; symbols are products of life and collective consciousness [23].

A symbol is the sign of a designated object; but it is 'not dead and motionless, it gives rise to multitudinous, perhaps even countless, general and single structures, which it signifies, in a general way, as a detachedly presented conceptual imagery' [13, p. 273]; it is the sign of an object which comprises separate semantic attributes that may contradict one another, and yet there is some general uniting principle behind them.

For utilitarian sign systems, 'polysemy is only a senseless obstacle that interferes with the rational functioning of a sign; by contrast, the more meanings a symbol has, the deeper its content is; after all, each true symbol has internal semantic coherence, due to which its content is every time correlated with "comprehensiveness" - with the idea of the entirety of the world, the wholeness of the cosmic and human "universum"' [2, p. 179].

According to S. Averintsev, a symbol is 'an image considered from the viewpoint of signness; it is a sign endowed with the entire organicity of myth and the infinite polysemy of an image' [1]. At the same time, any image is, at least to a certain extent, a symbol. The image is a category of artistic epistemology, the unity of form and content, it results from creative activity and has symbolic significance; perceiving an object, the subject of creative process (artist) confirms the validity of mimesis; an artistic image may be both a holistic phenomenon and its part. A. Potebnja (Thought and Language, 1862) regarded an image as the mapping of sensuously perceived reality in a person's mind where it acquires scientific and illustrative, factographic and artistic characteristics of the phenomena the author finds most relevant. From the semiotic perspective, the image is a specific sign, a fact of imagined reality that is constantly 'activated' by the author and a reader, both using the appropriate 
encoding/decoding key. Nowadays the notion of image is often substituted by the semiotic terms sign and signness [12, vol. 2, p. 139-140].

The image is defined as 'a specific form of artistic construction of reality, its inherent feature being vivid perceptibility' [12, vol. 2, p. 139]. The category of image involves the identity of a thing with itself, while the category of symbol highlights a different aspect of the same phenomenon - the image goes beyond its own boundaries; it involves a particular concept, semantics that merge with an image, but are not identical to it. The integral components of the structure of a symbol are a perceptible image and deep meaning; they are inseparable since beyond meaning an image breaks up into separate components, and meaning cannot emerge beyond an image. At the same time, they are the opposite poles; it is the tension between them that generates the essence of a symbol. Transforming into a symbol, an image becomes 'transparent', it passes through the symbol, being given semantic depth, semantic perspective, which requires a strenuous act of 'entering' itself [2, p. 178].

$\mathrm{Yu}$. Lotman states that symbols which are simple in their expression have greater cultural and content capacity than complex ones. Comparing the symbol with the emblem, the scholar points out that from the symbolic thinking perspective, 'the idea of translation' from one language (for example, verbal) into another (for example, graphical) is inherently paradoxical because both languages are in the state of untranslatability: the relationship between any symbol and its meaning is only partly conventional, which in its turn is causes 'a real semantic explosion' [15, p. 417]. A symbol works as 'a condensed progmamme of creative process', this factor precipitates the development of its potential. Additionally, such 'parent symbols' may emerge and develop quite unpredictably and abruptly in various plots [14, p. 239].

The content of symbols is rooted in human consciousness. From this perspective, they are 'something, one end of which is immersed in a given content of consciousness, and the other, in psychic existence, where certain content of consciousness is processed. It means that the very matter of a symbol must be present in consciousness in some modified form that is strangely different from its own (psychic) essence' [16, p. 129].

Decoding symbols involves comprehension of not only 'their meaning in the sense of ideas and the system of ideas', but also things that 'are beyond ideas, i.e. it involves revealing the meaning of symbols in the sense of covert, unexpressed in exoteric language of reality, human consciousness' [16, p. 123]. Comprehending symbols, the individual acquires certain information about human nature. From this perspective, the interpretation itself may be twofold: 'on the one hand, it is an exposition of symbols that enable the subject to know themselves and to find their own objective and unique qualities'; ' on the other hand, it is an indication of the subject's involvement in the situation, which has the objective conscious content. Here we deal with a primary symbol that is the thing which allows us to enter consciousness; while the former interpretation concerns itself with pseudo-symbols, i.e. things having symbolic meaning within an ideological or any other secondary system of interpretation' [16, p. 138].

M. Mamardashvili and A.Piatigorsky state that symbols exist only within interpretations that 'are not necessarily conscious - the ones in which consciousness reads itself. Most often, they are interpretations, in which culture reads itself giving various things, images, words, formulation (which, incidentally, may really turn out to be symbols) certain symbolic meanings and "entertaining the hope" that these things, images, words, formulation will suddenly "work", will suddenly turn out to be connected with the being of consciousness' $[16$, p. 168].

In terms of the metatheory of consciousness, the characteristics of the symbol are as follows: by its natural materiality, a symbol cannot directly correlate with one particular structure of consciousness; comprehension or incomprehension of a symbol depends not on an individual, but on the symbol itself; the relationship between a symbol and the structure of consciousness, with which it correlates, is not arbitrary; a symbol is capable of getting psyche into certain structures of consciousness on condition that the individual's psyche accumulates certain states of consciousness [16, p. 144-151].

According to R. Barthes, 'The symbolic consciousness implies an imagination of depth; it experiences the world as the relation of a superficial form and a many-sided, massive, powerful 
Abgrund, and the image is reinforced by a very intense dynamics: the relation of form and content is ceaselessly renewed by time (history), the superstructure overwhelmed by the infrastructure, without our ever being able to grasp the structure itself.' [24, p. 209-210]; [3, p. 251].

The signs of a symbolic ('cultural', connotative) message are discrete, and the composition of the representation presupposes that there is a certain aesthetic referent. In such a system, signs are 'supplied' from a certain cultural code, and the number of their possible interpretations may vary. However, the variability of interpretations is not arbitrary; it depends on different types of knowledge projected on a particular form of the representation (nationality, culture, religion, etc.). A symbol may be interpreted differently by different 'subjects' that co-exist in one and the same person and make use of different 'lexicons' (in the sense of the symbolicity of language). The number and identity of these lexicons form an individual's 'idiolect' [3, p. 312-313]. 'The image, in its connotation, is thus constituted by an architecture of signs drawn from a variable depth of lexicons (of idiolects); each lexicon, no matter how "deep", still being coded ...' [25, p. 47]; [3, p. 313]. Thus, symbols are an important device for acquiring hermeneutic knowledge; according to H.-G. Gadamer, hermeneutics is to be understood as 'a truth-experience in which we partake in that it can only unfold through a process of interpretation' [26]; [6, p. 139].

These considerations correlate with E. Cassirer's idea about the specific archetypal rootedness of symbols in human consciousness. 'Symbolic memory is the process by which man not only repeats his past experience but also reconstructs this experience. Imagination becomes a necessary element of true recollections' [27]; [11, p. 501].

P. Ricoeur, one of the leading representatives of philosophical hermeneutics, points out the specific nature of meaning hidden from history as it is understood in Christian theology. 'Faith in meaning, but in a meaning hidden from history, is thus both the courage to believe in a profound significance of the most tragic history (and therefore a feeling of confidence and resignation in the very heart of conflict) and a certain rejection of system and fanaticism, a sense of the open' [28, p. 96]; [18, p. 103].

In my opinion, symbols are one of the main factors in decoding the spiritual meaning of national and religious history. It concerns not only the instrumental and semantic interpretation of the content of symbols, but also the general process of cognition of the world because according to H.-G. Gadamer's hermeneutic 'manifesto', 'The understanding and interpretation of texts is not exclusively a concern of the human sciences, but obviously belongs to human experience of the world in general' [29]; [7, p. 7].

Symbols represented in the continuum of culture are not perceived as things; instead, 'we have only the ideological sphere of their outer (cultural) usage, which we use as an object of observation, and through which we intend to reconstruct conscious life or at least to understand something about how our own psychic mechanism works in what refers to the content of consciousness within which we exist' [16, p. 132].

Symbols are capable of containing capacious texts. At the same time, according to Yu. Lotman, a symbol 'preserves its semantic and structural independence. It can readily be picked out from its semiotic context and just as readily enter a new textual context. A symbol never belongs only to one synchronic section of culture; it always cuts across that section vertically, coming from the past and passing on into the future. A symbol's memory is always more ancient that the memory of its nonsymbolic text-context. <...> Symbols are among the most stable elements of the cultural continuum' [30, p. 103-104].

E. Sapir claims that any action can be regarded as purely functional in the literal meaning of the word or as symbolic or as the one that combines these two aspects. 'A primitive sign has some objective resemblance to what it takes the place of or points to.' For example, 'To knock on the door is a substitute for the more primitive act of shoving it open of one's own accord. <...> As time goes on, symbols become so completely changed in form as to lose all outward connection with what they stand for. Thus, there is no resemblance between a piece of bunting colored red, white, and blue, and the United states of America - itself a complex and not easily definable notion. The flag may therefore be looked upon as a secondary or referential symbol. <...> it is not surprising that philosophy, in 
attempting to understand knowledge and the meaning of symbolisms, is compelled to make a preliminary critique of the linguistic process itself.' The researcher comes to the conclusion that 'The way to understand language psychologically is to see it as the most complicated example of such a secondary or referential set of symbols that society has evolved' [31, p. 164-165]; [19, p. 133-135].

A symbol is a dialogic form of cognition because 'its content can be revealed only through human communication; beyond it, symbol degenerates into an empty form' [20, p. 579]. We not only analyze and interpret a symbol as an object, 'at the same time, we let its creator address us, be a partner in the work of our mind. A thing allows us to examine itself, while a symbol "watches" us' [2, p. 181].

The function of a symbol is to make the individual experience the states which cannot be independent realities of the world.

According to C. G. Jung, symbols are words or images whose meaning goes beyond clear and unambiguous definition; symbols help to understand the unconscious, and dream symbols are of special interest; dreams and symbols should be regarded from the point of view of causality and finality. S. Freud claimed that dreams were caused by repressed wishes, while C. G. Jung was convinced that dreams were 'the manifestation of the unconscious' [21]. C. G. Jung differentiated between individual and collective symbols. To the latter category he assigned the symbols of religion, which for centuries had been refined in particular religious and cultural traditions, and stated that they gave a person's life deep meaning and purpose. The founder of analytical psychology regretted that modern, 'civilized' people had deprived themselves of the ability to perceive secondary impulses sent by the instinctive, archaic basis of the mind and the unconscious; the symbols of the Divine, whose holiness was generally recognized, served our ancient ancestors as a means of a holistic perception of the world [21].

The role of sacred symbolism in the structure of the language of religion is evident. A modern Russian researcher M. Yeresko claims that there exists a direct connection between the nature of the human religious quest, its historical and cultural aspects on the one hand, and the language of religion, its symbolic component on the other. According to her, 'Human transcendent aspirations as well as the need for higher (absolute) legitimizing meaning are the cause - not the result - of the genesis of religion because they are formed by the very cognitive nature of the individual and are realized in various forms of culture. The genesis of religion is conditioned by the genesis of the architectonics and mechanics of its language. In the process of its evolution, the latter blends archaic and latest elements of the religious sphere of symbols, thus creating the invariant semantic sphere of religion, in which 'timeless' symbolic constructions are the result of the socialization of sociocultural invariants. The inherited from the language of myth inversion between the object and the subject of the language of religion ensures the legitimacy and the general value of the language subject as well as its substantial status in the system of religion and its fundamental role in the reproduction of this system in historical self-assertion' [9, p. 21].

Sacred symbolism is an important factor in the comprehension of cultural and national traditions. A symbol highlights the conceptual elements of the national picture of the world; it enables us to perceive them as aesthetic and artistic images; as a result, this picture is presented in its systemic unity. The paradoxical and conventional nature of symbol ensures the synthesis of separate elements in cultural/national megatexts. In the individual process of cognition, a symbol may become a conventional means of combining and 'coordinating' the conscious and the unconscious, the rational and the mystic, the scientific and the artistic. Symbols create the situations of both closeness, involvement, and remoteness, distance. In order to avoid the latter (unless there is a deliberate intention to hide belonging to a particular national group), it is necessary to decode dynamic symbolic images, which indicate the depth of national experience, heighten the sense of 'responsibility' for the cognition and further transformation of the world through the process of communication.

G.W.F. Hegel put forward the idea of 'the Spirit of the people' and various spheres of its manifestation, 'Thus is it with the Spirit of a people: it is a Spirit having strictly defined characteristics, which erects itself into an objective world, that exists and persists in a particular religious form of worship, customs, constitution, and political laws - in the whole complex of its institutions - in the 
events and transactions that make up its history. That is its work - that is what this particular Nation is. Nations are what their deeds are. $<\ldots>$ In this its work, therefore - its world - the Spirit of the people enjoys its existence and finds its satisfaction' [32, p. 90-91]; [8, p. 121]. In my opinion, symbolism is a strong manifestation of the national spirit.

In Ukrainian culture, a long period of national genesis has resulted in the formation of a unique conceptual semiosis. Intimately ingenuous perception of religious semantics is typical of the Ukrainian national code of Christian symbols, cf. the exquisite academicism or the mystic aura of the Catholic tradition, secular and utilitarian Protestant perception.

The following example - the analysis of just one element of the sacred church architecture in Ukraine - illustrates the originality of the Ukrainian symbolic world view. A characteristic element of Ukrainian wooden temple structures is the multi-tiered roof (an alternative to the flat roof) - a towerlike $\log$ construction of a considerable height, up to 37 metres. The construction was dubbed zalom, the word means 'a ledge on a multi-tiered roof structure that results from joining two structural elements the truncated pyramid and the vertical log construction'. Four-sided, six-sided, or eight-sided truncated pyramid prisms were put on top of one another, each upper prism being smaller than each lower one. The design helped to achieve harmony between the interior and exterior of the structure; there were no main and secondary facades, such a church looked equally attractive viewed from all sides. This feature distinguishes Ukrainian wooden sacred architecture from that of our closest neighbours. For example, Polish wooden churches are modeled on the canonical principles of the Gothic stone church architecture.

Zalom is unique to Ukrainian wooden architecture; it is a truly original design from both the constructional and the artistic perspective. A high tower crowns the structure; also, it creates the effect of vertical orientation of the church interior [5, p. 30-31]. It is a distinct symbolic form of communication with a general religious semantics of ascent, aspiration to the sky, to the ideal world of the sacred. The top/bottom spatial-semantic opposition is a key element in the Ukrainian system of ethic symbols and in the people's picture of the world - top is positive/good, while bottom is negative/bad; Heaven (Paradise) is contrasted to the underworld (Hell); cf. 'to ascend to Heaven' - 'to fall to Hell' [10, p. 77]. The role of these symbolic connotations in church architecture is obvious.

Complex transformations of the pagan mythological heritage and the system of its symbols affected the development of Ukrainian Christian symbolism. The canonical biblical interpretative referent in its Byzantine alloform was transformed according to the East Slavic/Ukrainian philosophical picture of the world presented through the internal form/connotations of Christian symbolism.

I claim that Ukrainian religious world view with its original mental and metaphysical approaches has naturally adapted the borrowed system of Christian sacred symbols to its own linguistic, cultural, philosophic, and ideological needs. Various factors contributed to the formation of the Christian symbolic code in Ukraine, its basic elements being the Byzantine and the autochthonous (pagan) codes. The cultural impact of the dominant Byzantine factor is traced through the $9^{\text {th }}$-the $18^{\text {th }}$ centuries. The Byzantine symbolic referent belonged to the official sphere of the Christian cult, while the pagan one was ousted into the domain of people's culture. It should be mentioned though, that even in the high forms of art (literature, architecture, etc.) the influence of the pre-Christian connotations is evident.

To conclude, symbols and signs are among the decisive factors in the evolution of religious and national pictures of the world. A symbol is the 'superstructure' element of a particular religious and national meaning; it gets transformed and develops a new, non-literal meaning: a certain concept (an abstract notion, an object, a person, an action, etc.) is the initial object of symbolic narrative; later, in a situation of distributional restriction, there occurs desemanticization of the concept and the latter takes the symbolic form of a perceptible image, which generates a multiplicity of connotative meanings in a religious/cultural interactive context. 


\section{REFERENCES}

[1] Аверинцев С. Символ. Електронний ресурс. Режим доступу: http://www.gumer.info /bibliotek_Buks/Literat/aver.

[Averyntsev S. Symvol. Available at: http://www.gumer.info /bibliotek_Buks/Literat/aver.]

[2] Аверинцев С. Софія-Догос: словник. Дух і Літера, К., 2004.

[Averyntsev S. Cofiia - Lohos: slovnyk. Dukh i Litera, K., 2004.]

[3] Барт Р. Избранные работы: Семиотика: Поэтика (пер. с фр., сост., общ. ред. и вступ. ст. Косикова Г.К.). Прогресс, М., 1989.

[Bart R. Yzbrannye raboty: Semyotyka: Poetyka (per. s fr., sost., obshch. red. y vstup. st. Kosykova H.K.). Prohress, M., 1989.]

[4] Бахтин М.М. К истории формального метода. В: Бахтин М.М. Тетралогия (сост., текстолог. подготовка, научн. аппарат Пешкова И.В.). Лабиринт, М., 1998, 150-187.

[Bakhtyn M.M. K ystoryy formalnoho metoda. V: Bakhtyn M.M. Tetralohyia (sost., tekstoloh. podhotovka, nauchn. apparat Peshkova Y.V.). Labyrynt, M., 1998, 150-187.]

[5] Вечерський В. Українські дерев'яні храми. Наш час, К., 2007.

[Vecherskyi V. Ukrainski dereviani khramy. Nash chas, K., 2007.]

[6] Гадамер Г.-Г. Вірш і розмова. Есе, пер. $з$ нім. Незалежний культурологічний журнал “Ї", 2002.

[Gadamer H.-G. Virsh i rozmova. Ese, per. z nim. Nezalezhnyi kulturolohichnyi zhurnal "Yi", 2002.]

[7] Гадамер Г.-Г. Істина i метод, Т. 1: Герменевтика I: Основи філософської герменевтики; пер. 3 нім. Юніверс, К., 2006.

[Gadamer H.-G. Istyna i metod, T. 1: Hermenevtyka I: Osnovy filosofskoi hermenevtyky; per. z nim. Yunivers, K., 2006.]

[8] Гегель Г.В.Ф. Аекцุии по философии истории; пер. с нем. Наука, СПб., 2000.

[Hehel H.V.F. Lektsyy po fylosofyy ystoryy; per. s nem. Nauka, SPb., 2000.]

[9] Ересько М.Н. Язык религии: философски - когнитивный анализ: Автореф.дис. на соиск. учен. степ. докт. филос. наук. М., 2008.

[Eresko M.N. Yazyk relyhyy: fylosofsky - kohnytyonyi analyz: Avtoref.dys. na soysk. uchen. step. dokt. fylos. nauk. M., 2008.]

[10] Жайворонок В.В. Знаки української етнокультури: словник-довідник. Довіра, К., 2006.

[Zhaivoronok V.V. Znaky ukrainskoi etnokultury: slovnyk - dovidnyk. Dovira, K., 2006.]

[11] Кассирер Э. Избранное. Опыт о человеке. Гардарика, М., 1998.

[Kassyrer E. Yzbrannoe. Opyt o cheloveke. Hardaryka, M., 1998.]

[12] Ковалів Ю.І. (Авт.-укл.) Літературознавча енцииклопедія: у двох томах. ВЦ “Академія”, К., 2007.

[Kovaliv Yu.I. (Avt.-ukl.) Literaturoznavcha entsyklopediia: u dvokh tomakh. VTs “Akademiia", K., 2007.]

[13] Лосев А.Ф. Философия. Мифология. Культура. Политиздат, М., 1991.

[Losev A.F. Fylosofyia. Myfolohyia. Kultura. Polytyzdat, M., 1991.]

[14] Лотман Ю.М. Внутри мыслящих миров. В: Аотман Ю.М. Семиосфера. “Искусство СПб”, СПб, 2000. [Lotman Yu.M. Vnutry mysliashchykh myrov. In: Lotman Yu.M. Semyosfera. "Yskusstvo $\mathrm{SPb}$ ", $\mathrm{SPb}$, 2000.]

[15] Лотман Ю.М. Между эмблемой и символом. В: Пермяков Е.В.(Составитель) Яотмановский сборник, Т.2. Изд-во РГГУ, изд-во “ИЦ-Гарант”, 1997, 416-424.

[Lotman Yu.M. Mezhdu emblemoi y symvolom. In: Permiakov E.V.(Sostavytel) Lotmanovskyi sbornyk, T.2. Yzd-vo RHHU, yzd-vo "YTs-Harant", 1997, 416-424.]

[16] Мамардашвиди М.К. Символ и сознание. Метафизические рассуждения о сознании и языке. Школа “Языки русской культуры”, М., 1997.

[Mamardashvyly M.K. Symvol y soznanye. Metafyzycheskye rassuzhdenyia o soznanyy y yazyke. Shkola "Iazyky russkoi kultury", M., 1997.]

[17] Новейший философский словарь, 2-е изд., переработ. и дополн. Интерпрессервис, Книжный дом, Минск, 2001.

[Noveishyi fylosofskyi slovar, 2-e yzd., pererabot. y dopoln. Ynterpresservys, Knyzhnyi dom, Mynsk, 2001.] 
[18] Рікер П. Історія та істина (пер. з фр.). Вид-ий дім “КМ Асаdemia”, Університ. вид-во “Пульсари", 2001.

[Riker P. Istoriia ta istyna (per. z fr.). Vyd-yi dim "KM Academia", Universyt. vyd-vo "Pulsary", 2001.]

[19] Сепир Э. Статус лингвистики как науки. В: Сепир Э. Языки как образ мира. ООО “Изд-во АСТ”, M., Terra Fantastica, СПб, 2003, 127-139.

[Sepyr E. Status lynhvystyky kak nauky. In: Sepyr E. Yazyky kak obraz myra. OOO "Yzd-vo AST", M., Terra Fantastica, SPb, 2003, 127-139.]

[20] Філософський енциклопедичний словник. Абрис, К., 2002. [Filosofskyi entsyklopedychnyi slovnyk. Abrys, K., 2002.]

[21] Юнг К.Г. К вопросу о подсознании. В: Юнг К.Г., фон Франц М.-А., Хендерсон Дж. Л., Якоби И., Яффе А. Человек и его символьы. Медков С.Б., "Серебряные нити", М., 2006, 14-105.

[Iunh K.H. K voprosu o podsoznanyy. In: Yunh K.H., fon Frants M.-L., Khenderson Dzh. L., Yakoby Y., Yaffe A. Chelovek y eho symvoly. Medkov S.B., "Serebrianye nyty", M., 2006, 14-105.]

[22] Korher E.J. Myslenie w kategoriach symboli. Horyzonty wiary, 3 (1995), 3-14.

[23] Naud J. Simbolismo. In: Naud J. Dizinario di Teologia Fondamentale; a cura di R. Latourelle e R. Fisichella.Cittadella, Assisi, 1990.

[24] Barthes R. Critical Essays (translated from the French by Richard Howard). Northwestern University Press, Evanston, 1972. Available at: https://books.google.com.ua/books?isbn=0810105896.

[25] Barthes R. Image Music Text (Essays selected and translated by Stephen Heath). Fontana Press, An Imprint of HarperCollinsPublishers, London, 1977. Available at: https://rosswolfe.files.wordpress.com /2015/04/roland-barthes-image-music-text.pdf.

[26] Hermeneutics-Gadamer's Hermeneutics Of The Event Of Understanding. Available at: http://science. jrank.org/pages/9617/Hermeneutics-Gadamer-s-Hermeneutics-Event-Understanding.html.

[27] Cassirer E. An Essay on Man: An Introduction to a Philosophy of Human Culture. Yale University Press, New Haven, 1972.

[28] Ricoeur P. History and Truth. Charles A. Kelbley. Northwestern University Press, Evanston, 1965. Available at: https://books.google.com.ua/books?id=6vU6gvDqZLoC\&printsec=frontcover\&dq $=$ P.+Ricoeur.+History+and+truth\&hl=uk\&sa=X\&ved=0ahUKEwin2vXsyq3QAhVHjSwKHbpnDwkQ6AE IIjAA\# $\mathrm{v}=$ onepage\&q=P.\%20Ricoeur.\%20History\%20and\%20truth\&f=false.

[29] Gadamer H.-G. Truth and Method (translation revised by Weinsheimer J. and Marshall D. G.). Bloomsbury, London, New Delhi, New York, Sydney, 2013.

[30] Lotman Yu.M. Universe of the Mind. A Semiotic Theory of Culture. Introduction by Umberto Eco (Translated by Ann Shukman). I.B. Tauris Publishers, London, New York, 2001. Available at: https://books.google.com.ua/books?id=kKsARW8QuXQC\&pg=PA104\&lpg=PA104\&dq=symbol+never+ belongs+to+one+particular+culture\&source.

[31] Sapir E. Selected Writings of Edward Sapir in Language, Culture and Personality (edited by David Goodman Mandelbaum, with a New Epilogue by Dell H. Hymes). University of California Press, Berkeley, Los Angeles, London, 1985. Available at: https://books.google.com.ua/books?id=1mqkkpbsgHYC\&pg $=$ PA165\&dq="critique+of+the+linguistic+process+itself".

[32] Hegel G.W.F. The Philosophy of History (with Prefaces by Charles Hegel and the Translated by Sibree J.) Batoche Books, Kitchener, Ontario, Canada, 2001. Available at: http://socserv2.socsci.mcmaster.ca / econ/ugcm/31l3/hegel/history.pdf.

Address: Ivan Ostashchuk, Vasyl Stefanyk Precarpathian National University, 57, Shevchenko Str., IvanoFrankivsk, 76025, Ukraine.

E-mail: kf@pu.if.ua.

Received: 31.07.2017; revised: 25.09.2017. 
Остащук Іван. Знаки і символи: релігійне й національне. Журнал Прикарпатського університету імені Василя Стефаника, 4 (2) (2017), 88-96.

У статті досліджено смислове наповнення і концептуальне розуміння понять символу й знака в філософсько-релігійному та лінгвокультурологічному контекстах. Розкривається логіка символічного мислення в процесах комунікації. Аналізується важливість символів та знаків у процесі передавання інформації в релігійному й національному універсумах.

Кдючові слова: симвод, знак, релігійний світогляд, національний код, комунікація. 